\title{
PERLINDUNGAN HUKUM PELAUT DI KAPAL INDONESIA BERBASIS NILAI KEADILAN
}

\author{
Tri Cahyadi \\ Dosen PIP Semarang \\ tricahyadi@yahoo.com
}

\begin{abstract}
This paper discusses the legal protection for sailors on Indonesian Ships amid the many problems experienced by Indonesian sailors. The belence between what has been done with the wages received by Indonesian sailors should be felt by Indonesian sailors has not been releazed, where in case of industrial relation disputes so far can not be resolved fairly, especially about the work place that is on the ship with the location always nomaden. Primary data sources were obtained from interviewers with several Indonesia sailors, as well as the secondary data sources of reference related legislation. The results show that many Indonesian sailors who are unaware of the legal certainty/lack of awarness and understanding of sailors about the relevant law or regulation are factors inhibiting implementation in the field. In addition, low discipline in the management of income to ensure life on the old days.
\end{abstract}

Keywords : Legal protection, sailors, justice.

\begin{abstract}
Abstrak
Tulisan ini membahas tentang perlindungan hukum bagi pelaut di Kapal Indonesia di tengah banyaknya permasalahan-permasalahan yang dialami oleh pelaut Indonesia. Keseimbangan antara yang sudah dikerjakan dengan upah yang diterima oleh pelaut Indonesia yang seharusnya dirasakan oleh pelaut Indonesia selama ini tidak terlaksana, dimana apabila terjadi perselisihan hubungan industrial selama ini belum bisa terselesaikan secara adil, terlebih lagi mengenai tempat bekerja yaitu di atas kapal dengan lokasi yang selalu berpindah-pindah. Sumber data primer diperoleh dari wawancara dengan beberapa pelaut Indonesia, serta sumber dara sekunder dari referensi perundang-undangan terkait. Hasilnya menunjukkan banyak pelaut Indonesia yang tidak mengetahui kepastian hukum yang ada/kurangnya kesadaran dan pemahaman pelaut tentang undang-undang atau peraturan yang terkait menjadi faktor penghambat implementasi di lapangan. Selain itu rendahnya kedisiplinan dalam pengelolaan pendapatan untuk menjamin kehidupan di hari tua.
\end{abstract}

Kata Kunci : Perlindungan hukum, pelaut, keadilan.

\section{A. Latar Belakang}

Indonesia merupakan negara kepulauan dengan jumlah pulau kurang lebih $17.508,{ }^{1}$ hal ini merupakan suatu anugerah dan tantangan terutama dalam penyediaan transportasi laut. Perkembangan jasa transportasi laut nasional sampai saat ini mengalami pasang dan surut seiring dengan pengaruh yang diakibatkan oleh perubahan kebijakan oleh pemerintah dan juga dari pemangku kepentingan dalam penyediaan transportasi laut.

\footnotetext{
1 http://en.wikipedia.org/wiki/Indonesia
}

Awal tahun 2005, banyak ditemui kapalkapal berbendera asing berlalu lalang di perairan Indonesia. Mereka mengambil bagian dalam pengangkutan komoditas antar-pulau yang mestinya menjadi porsi perusahaan-perusahaan pelayaran nasional. Namun, sejak diterbitkannya Inpres Nomor 5 Tahun 2005 tentang Pemberdayaan Industri Pelayaran Nasional kondisinya mulai berbalik. Dalam rangka mengoptimalkan pelaksanaan kebijakan Pemberdayaan Industri Pelayaran Nasional, dengan ini menginstruksikan untuk menerapkan asas cabotage secara 
konsekuen dan merumuskan kebijakan serta mengambil langkah-langkah yang diperlukan sesuai dengan kewenangan masing-masing guna memberdayakan industri pelayaran nasional. ${ }^{2}$

Menteri Koordinator Bidang Perekonomian mengkoordinasi pelaksanaan Instruksi Presiden ini dan melaporkan secara berkala kepada Presiden. Kebijakan tentang asas cabotage tersebut mencakup 6 (enam) bidang yang meliputi bidang perdagangan, bidang keuangan, bidang perhubungan, bidang perindustrian, bidang energi dan sumber daya mineral dan bidang pendidikan dan latihan. Pelaksanaan kebijakan tersebut di bidang perhubungan berhasil mendorong industri pelayaran Nasional berkembang dengan pesat ditunjukkan dengan hasil pendataan Direktorat Jenderal Perhubungan Laut dan INSA (Asosiasi Pengusaha Pelayaran Seluruh Indonesia) tentang jumlah kapal Indonesia dengan hasil sebagai berikut: pada tahun 2005 ada 6.400 kapal Indonesia yang mengangkut komoditas perdagangan dalam negeri, dan di tahun 2012 terdapat 11.495 kapal sehingga ada peningkatan signifikan sebesar $90 \%$ dilihat dari segi jumlah kapal. ${ }^{3}$

Penambahan jumlah Kapal Indonesia tersebut di atas jika diakumulasi jumlah kapasitas angkutan pelayaran seluruh Indonesia sebesar 280 juta ton/tahun, dengan tujuh jenis pelayaran seperti Angkutan Tongkang, Penumpang-kendaraan, muatan cair, Curah kering, Barang umum, angkutan Kontainer, dan angkutan Lepas Pantai. Sebagai konsekwensi logis dari hal tersebut adalah peningkatan kebutuhan awak kapal (pelaut) di dalam negeri, dan sesuai Inpres maka kapal berbendera Indonesia harus diawaki oleh pelaut Indonesia. Namun demikian yang terjadi saat ini seperti yang dijelaskan oleh INSA bahwa kapalkapal Indonesia sangat kekurangan awak kapal. Kekurangan awak kapal tersebut dikarenakan pelaut Indonesia lebih menyukai untuk bekerja di kapal asing daripada di kapal-kapal Indonesia. "Sebagian besar lulusan pelaut di tingkat perwira maupun ABK lebih senang bekerja di kapal asing ketimbang di kapal berbendera Merah Putih milik

2 Instruksi Presiden Nomor 5 Tahun 2005. 28 Maret, 2010.

3 Direktorat Jenderal Perhubungan Laut dan INSA (Asosiasi Pengusaha Pelayaran Seluruh Indonesia) Tahun 2005. perusahaan pelayaran nasional, masalah gaji dan tunjangan menjadi penyebab utamanya". ${ }^{4}$

Kesenjangan kesejahteraan yang sangat besar adalah merupakan penyebab utama dari pelaut Indonesia lebih memilih bekerja di kapalkapal asing. Dengan bekerja di kapal-kapal asing para pelaut Indonesia akan mendapatkan gaji yang lebih besar daripada bekerja di Kapal Indonesia, di samping itu dari segi tunjangan juga lebih menjanjikan untuk bekerja di kapal-kapal asing daripada di kapal Indonesia. Hal tersebut tentu saja menjadi permasalahan nasional, di satu sisi kita mengharapkan peningkatan pelayanan pelayaran domestik yang diselenggarakan oleh armada swasta nasional yang tentu saja diikuti dengan meningkat pesatnya jumlah kapal berbendera indonesia.

Meningkatnya jumlah kapal Indonesia tersebut tentu saja harus diikuti dengan peningkatan jumlah awak kapal yang cukup signifikan, dalam kenyataannya seperti dijelaskan dalam penjelasan sebelumnya bahwa pelaut Indonesia lebih tertarik untuk bekerja di Kapal bendera asing. Saat ini untuk mengatasi kekurangan awak kapal di atas kapal berbendera Indonesia terutama kekurangan jumlah perwira kapal dan nakhoda kapal maka dilakukan sesuatu yang melanggar peraturan dari sisi keselamatan kapal yaitu fenomena Nakhoda Terbang. ${ }^{5}$

Pelanggaran lain yang dilakukan oleh perusahaan pelayaran Nasional sebagai dampak dari kurangnya jumlah Sumber Daya Manusia awak kapal adalah dengan memberikan tugas dan tanggung jawab kepada seseorang tidak sesuai dengan kompetensi ijazah yang dimiliki. Pemegang ijazah sesuai kualifikasi yang disyaratkan tidak ada yang bersedia untuk bekerja di kapal tersebut, sehingga terpaksa Direktorat Jenderal Perhubungan Laut memberikan dispensasi dengan mengijinkan kompetensi ijazah yang lebih rendah mengawaki kapal tersebut sehingga pelayaran dapat dilaksanakan.

Terpaksa dispensasi diberikan oleh Direktorat Jenderal Perhubungan Laut karena

Boby R. Mamahit, 2011, "Krisis SDM Masih Belum Bisa Teratasi”, Suara Karya, 26 Januari, hlm.1.

5 Dedi Darmawan, 2010,"Perusahaan Pelayaran Nasional Diimbau Aktif Mengembangkan Tenaga Pelaut", Berita Pusat Komunikasi Publik Kementerian Perhubungan, 13 April, hlm. 1. 
jika terjadi kekurangan armada kapal terutama yang menyangkut kebutuhan pengangkutan. Kekurangan armada kapal pengangkut terjadi karena kalau pemerintah tetap berpegang pada aturan yang berlaku mengenai persyaratan pengawakan kapal, maka banyak kapal tidak dapat mendapatkan ijin berlayar dari Administrator pelabuhan sebagai kepanjangan tangan dari Direktorat Jenderal Perhubungan Laut."Kebijaksanaan Publik adalah whatever governments choose to do or not to do". 6 Pendapat tersebut sesuai dengan kondisi dan situasi yang terjadi sehubungan dengan kebijaksanaan pemerintah dalam mengatasi mengatasi permasalahan kebutuhan transportasi laut yang terkendala pada saat ini sehubungan dengan keterbatasan jumlah awak kapal. Namun demikian hal tersebut juga tidak dapat menyelesaikan permasalahan sampai tuntas, tetapi akan timbul masalah baru.

Kecelakaan kapal antara KM. Indimatam V dengan KM. Trisal Pratama tanggal 4 Agustus 2010 terjadi antara lain karena adanya dispensasi kualifikasi pengawakan kapal. "Berdasarkan ketentuan dapat disimpulkan bahwa pengawakan kapal KM. Indimatam V dengan KM. Trisal Pratama belum memenuhi persyaratan yang ditentukan dalam Surat Keputusan Menteri Perhubungan No. 70 Tahun 1998, tentang Pengawakan Kapal Niaga". ${ }^{7}$

Melihat kenyataan di atas, lalu timbul pertanyaan bahwa golongan pekerja laut (pelaut) perlu mendapat perhatian menyeluruh secara global. Apa sajakah problematika perlindungan hukum pelaut di Kapal Indonesia saat ini? Serta bagaimanakah rekonstruksi perlindungan hukum pelaut di Kapal Indonesia berdasarkan nilai keadilan?

Dalam penelitian ini menggunakan acuan teori Constructivism, sesuai dengan tujuan penelitian yaitu terwujudnya kondisi dan situasi yang harmonis di antara peraturan perundang-undangan yang

6 Esmi Warassih, 2005, "Pranata Hukum Sebuah Telaah Sosiologis", Suryandaru Utama, Semarang, hlm. 131, dikutip dari Thomas R. Dye, 1978, "Understanding Public Policy", Prentice Hall, Inc. hlm. 3.

7 "Tubrukan Antara KM. Indimatam V dengan KM. Trisal Pratama”, 2011, Investigasi Kecelakaan Kapal Laut KNKT, Januari, hlm. 18. berkaitan dengan perlindungan pelaut yang bekerja di Kapal Indonesia, maka diharapkan tercapai penerapan nilai-nilai kesejahteraan dan keadilan sosial dalam mencapai kemakmuran bangsa. Hal ini digunakan sebagai model penyelesaian problematika yang dikembangkan atau dimodifikasi tersebut merupakan hasil dari perspektif manusia itu sendiri.

Penggunaan metode yuridis sosiologis dipilih untuk melihat sejauh mana efektifitas hukum dalam memberikan perlindungan kepada pelaut yang bekerja di Kapal Indonesia. Efektifitas hukum itu sendiri juga dipengaruhi faktor-faktor non hukum seperti lembaga terkait dan perilaku penegak hukum serta proses timbal balik dari masyarakat yang dikenai hukum tersebut. Hukum tidak dikonsepkan sebagai gejala normatif yang otonom akan tetapi institusi sosial yang secara riil berkaitan dengan variabel-variabel sosial lainnya.

\section{B. Hasil Penelitian dan Pembahasan}

1. Perlindungan hukum pelaut di Indonesia saat ini

Sebagai operator awak kapal memegang peran yang sangat penting untuk terselenggaranya layanan jasa transportasi laut yang aman, efisien dan ramah lingkungan. Agar awak kapal dapat menjalankan tugas dengan baik, tentu saja harus didukung dengan situasi dan kondisi kerja yang kondusif. Dikaji lebih lanjut, terjadi permasalahan-permasalahan yang menyangkut kesejahteraan awak kapal di kapal Indonesia, yaitu diantaranya :8

a. Pengaturan kesejahteraan mengenai gaji dan tunjangan masih bersifat umum belum ada standar yang baku tentang besaran gaji/ upah minimum serta tunjangan kerja.

b. Penyelesaian Perselisihan Hubungan Industrial tidak dapat diterapkan kepada para pelaut ketika terjadi konflik hubungan industrial.

c. Belum diratifikasinya Maritime Labour Convention (MLC) oleh pemerintah Indonesia.

8 Tri Cahyadi, Rekonstruksi Perlindungan Hukum Pelaut Di Kapal Indonesia Berbasis Nilai Keadilan Disertasi PDIH Unissula, Semarang. 
Sudah selayaknya manusia hidup dengan sejahtera di dalam kehidupannya berbangsa dan bernegara. Ungkapan tersebut tidaklah berlebihan, karena salah satu tugas negara adalah memastikan bahwa seluruh rakyatnya dapat hidup sejahtera. Saat ini muncul permasalahan yang cukup serius menyangkut kesejahteraan awak kapal yang bekerja di kapal Indonesia. tentu saja sesuai aturan yang berlaku saat ini awak kapal tersebut pasti Warga Negara Indonesia. ${ }^{9}$

2. Problematika perlindungan hukum pelaut di Kapal Indonesia saat ini a. Subtansi Hukum

Perlu dipahami bahwa Substansi hukum menurut Friedman adalah ${ }^{10}$.

"Another aspect of the legal

system is its substance. By this

is meant the actual rules, norm, and behavioral patterns of people inside the system ...the stress here is on living law, not just rules in law books".

Aspek lain dari sistem hukum adalah substansinya. Substansi di sini adalah Aturan, Norma, dan Pola Perilaku nyata manusia yang berada dalam system itu. Jadi substansi hukum menyangkut peraturan perundang-undangan yang berlaku yang memiliki kekuatan yang mengikat dan menjadi pedoman bagi aparat penegak hukum.

Permasalahan yang sering terjadi pada aspek substansi hukum menyangkut penyelesaian permasalahan kesejahteraan awak kapal di kapal Indonesia masih terjadi karena pedoman peraturannya masih multitafsir dan tidak langsung dapat menjawab permasalahan yang terjadi di lapangan. Diantaranya adalah:

1) Pengaturan kesejahteraan mengenai gaji dan tunjangan

"Undang - Undang Nomor 17 Tahun 2008 Tentang Pelayaran", Lembaran Negara Republik Indonesia Tahun 2008 Nomor 64.

10 Lawrence M. Friedman, 1984, American Law: An invalueable guide to the many faces of the law, and how it affects our daily lives, New York: W.W. Norton \& Company, hlm. 5-6 masih bersifat umum belum ada standar yang baku tentang besaran gaji / upah minimum serta tunjangan kerja pelaut.

Sesuai dengan Pasal 151 UndangUndang Nomor 17 Tahun 2008 tentang Pelayaran, disebutkan bahwa: kesejahteraan pelaut meliputi gaji, jam istirahat, jaminan pemberangkatan ke tempat tujuan dan pemulangan ke tempat asal, kompensasi apabila kapal tidak dapat beroperasi karena mengalami kecelakaan, kesempatan mengembangkan karier, pemberian akomodasi, fasilitas rekreasi, makanan atau minuman, pemeliharaan dan perawatan kesehatan serta pemberian asuransi kecelakaan kerja ${ }^{11}$.

Semua hal yang menyangkut kesejahteraan masih diatur secara umum dan belum ada acuan dasar. Pemerintah memang sudah menetapkan Upah Minimum Kota/ Kabupaten untuk tenaga kerja secara umum, namun demikian hal tersebut tidak dapat dijadikan acuan untuk gaji serta tunjangan yang harus dibayarkan kepada pelaut. Selain kesenjangan yang cukup besar antara perusahaan dalam negeri dan perusahaan asing, dapat dimengerti bahwa bekerja di kapal mengandung resiko yang cukup tinggi sehingga memerlukan pengetahuan dan keterampilan khusus yang memadai.

Sedangkan hasil wawancara kepada seorang Nahkoda Kapal Indonesia diantaranya adalah:

"Kesejahteraan pelaut itu mencakup sebelas aspek meliputi: gaji dan tunjangan, permakanan yang baik, tempat tinggal yang layak, waktu istirahat, kesempatan untuk cuti, perawatan kesehatan, santunan bila terjadi kecelakaan, pemulangan kembali ke tempat asal, pesangon bila kapal dijual

11 Pasal 151 Undang-Undang Nomor 17 Tahun 2008 tentang Pelayaran 
kepada pihak lain, ganti rugi barang kita bila kapal tenggelam dan adanya jaminan pelaksanaan kerja yang mengedepankan unsure keselamatan"12.

Penulis memahami bahwa hasil wawancara tersebut menjelaskan bahwa: aspek tersebut mutlak harus dipenuhi semua, sehingga para pelaut, melaksanakan tugas dengan baik dan sempurna, sesuai dengan tugas dan tanggung jawabnya masing-masing. Selain itu juga para pelaut merasakan ketenangan hati dalam menjalankan tugas, tentunya ketenangan tersebut berpengaruh kepada semangat dan motivasi kerja, sehingga hasil yang diharapkan sesua harapan.

Peraturan tentang gaji dan tunjangan tersebut diharapkan dapat menjadi acuan besaran nominal gaji dan tunjangan yang ideal, dalam arti tidak terlalu berbeda jauh dengan standar internasional menyangkut gaji dan tunjangan. Penulis mengulas bahwa: perbedaan gaji yang rentangnya yaitu sampai empat atau lima kali lipat, serta kurang memenuhi gaji para pelaut yang di atas kapal indonesia, sebagaimana hasil wawancara "Gaji tertinggi di kapal tersebut adalah sekitar sebelas juta rupiah dan gaji terendah sekitar satu juta lima ratus ribu rupiah ${ }^{13}$." selain itu pula sama - sama bekerja dengan resiko tinggi sehingga para pelaut cenderung berharap untuk menjadi pelaut di kapal asing.

2) Belum diratifikasinya Maritime Labour Convention (MLC) oleh pemerintah Indonesia.

Dari hasil sidang umum The International Labour Organization

12 Hasil wawancara dari seorang Nahkoda Kapal Indonesia bernama Eko Supriyanto dari perusahaan Surabaya, tempat wawancara: Pelabuhan Surabaya, Selasa, 2 Februari 2016.

13 Hasil wawancara dari seorang Nahkoda Kapal Indonesia bernama Eko Supriyanto dari perusahaan Surabaya, tempat wawancara: PT. Surabaya Dockyard Surabaya, Selasa 2 Februari 2016.
(ILO) tanggal 7 Pebruari $2006 \mathrm{di}$ Geneva, diputuskan tentang proposal dari Maritime Labour Conventions (MLC) ${ }^{14}$. Hal ini berisi tentang konvensi-konvensi ILO sebelumnya yang masih terpisah satu sama lain. Sedangkan di dalam MLC semua konvensi yang menyangkut tenaga kerja pelaut dikumpulkan menjadi satu, sehingga bila suatu negara menyatakan meratifikasi dari konvensi ini berarti akan memberlakukan semua isi konvensi yang ada di dalamnya.

Mengingat hal tersebut maka untuk memastikan kesejahteraan awak kapal yang bekerja di atas kapal, sudah seharusnya pemerintah segera diratifikasi tentang konvensi tersebut. Hal ini dilakukan demi terwujudnya perlindungan kesejahteraan tenaga kerja dalam hal ini awak kapal.

b. Struktur Hukum

Berkenaan dengan struktur hukum Friedman menjelaskan ${ }^{15}$ :

"To begin with, the legal sytem has the structure of a legal system consist of elements of this kind: the number and size of courts; their jurisdiction ...Strukture also means how the legislature is organized ...what procedures the police department follow, and so on. Strukture, in way, is a kind of crosss section of the legal system .... kind of still photograph, with freezes the action

Artiya: Struktur dari sistem hukum terdiri atas unsur berikut ini, jumlah dan ukuran pengadilan, yurisdiksinnya (termasuk jenis kasus yang berwenang mereka periksa), dan tata cara naik banding dari pengadilan ke pengadilan lainnya. Struktur juga berarti bagaimana badan legislative ditata, apa yang boleh dan tidak boleh dilakukan oleh presiden, prosedur ada yang diikuti

14 "Maritime Labour Convention", 7 February, 2006.

15 Lawrence M. Friedman, 1984, Op.Cit., hlm. 5-6 
oleh kepolisian dan sebagainya. Jadi struktur (legal struktur) terdiri dari lembaga hukum yang ada dimaksudkan untuk menjalankan perangkat hukum yang ada.

Di Indonesia misalnya jika kita berbicara tentang struktur sistem hukum Indonesia, maka termasuk di dalamnya struktur institusi-institusi penegakan hukum seperti kepolisian, kejaksaan dan pengadilan ${ }^{16}$.

Problematika yang terjadi pada aspek struktur hukum menyangkut penyelesaian permasalahan kesejahteraan awak kapal di kapal Indonesia masih terjadi karena belum ada lembaga peradilan khusus yang menangani hal tersebut. Diantaranya adalah :

1) Penyelesaian perselisihan hubungan industrial pelaut di Pengadilan Hubungan Industrial belum mampu menyelesaikan permasalahan yang terjadi.

Struktur adalah Pola yang menunjukkan tentang bagaimana hukum dijalankan menurut ketentuanketentuan formalnya. Struktur ini menunjukkan bagaimana pengadilan, pembuat hukum dan badan serta proses hukum itu berjalan dan dijalankan. Dalam istilah penyelesaian perselisihan ada beberapa hal penting, yaitu: Perselisihan Hubungan Industrial, Perselisihan hak dan Perselisihan kepentingan. ${ }^{17}$ Perselisihan Hubungan Industrial adalah perbedaan pendapat yang mengakibatkan pertentangan antara pengusaha atau gabungan pengusaha dengan pekerja/buruh atau serikat pekerja/serikat buruh karena adanya perselisihan mengenai hak, perselisihan kepentingan, perselisihan pemutusan hubungan

16 Achmad Ali, 2002, Menguak Tabir Hukum Suatu Kajian Filosofis dan Sosiologis, PT. Gunung Agung Tbk, Jakarta, hlm.8

17 "Undang - Undang Nomor 13 Tahun 2003 Tentang Ketenagakerjaan", Lembaran Negara Republik Indonesia Tahun 2003 Nomor 9. kerja dan perselisihan antar serikat pekerja/serikat buruh dalam satu perusahaan.

Penyelesaian Perselisihan Hubungan Industrial (PPHI) hanya mengatur hubungan industrial secara umum, khususnya tenaga kerja yang bekerja di darat, sedangkan pelaut yang bekerja di kapal tidak diatur secara khusus. Permasalahan tentang pengaturan tempat bekerja dan tempat terjadinya perselisihan akan menjadi polemik yang serius. Di dalam Perjanjian Kerja Laut telah diatur mengenai tempat bekerja yaitu di atas kapal dengan lokasi yang selalu berpindah-pindah. Bila selama bertugas di atas kapal dengan tempat yang selalu berpindah-pindah maka kepastian tempat perselisihan juga menjadi masalah tersendiri. Hal ini sangat berpengaruh terhadap ketentuan yang dijadikan dasar oleh Pengadilan Hubungan Industrial dalam menentukan misalnya masalah Gaji, yaitu mengacu pada aturan setempat atau aturan di mana PKL ditandatangani. Sebagai contoh, misalnya $\mathrm{PKL}$ ditandatangani di Jakarta, kemudian kapal berlayar ke Sorong dan selama pelayaran terjadi perselisihan. Penyelesaian masalah tersebut tentu saja akan dilakukan di PHI Sorong, bukan di Jakarta.

Dari uraian di atas maka di dalam tubuh Pengadilan Hubungan Industrial perlu dilakukan pembidangan khusus untuk menangani permasalahan hubungan industrial antara pelaut dan pengusaha kapal. Penataan kembali tata kelola dari $\mathrm{PHI}$ diperlukan untuk dapat mengakomodir semua permasalahan hukum ketenagakerjaan yang dinamis sesuai dengan perkembangan jaman.

2) Aparat penegak hukum yang masih berparadigma positivisme dalam mengambil keputusan di lembaga peradilan. 
Diakui maupun tidak bahwa hukum sebagai alat untuk mengubah masyarakat atau rekayasa sosial tidak lain hanya merupakan ideide yang ingin diwujudkan oleh hukum itu. Untuk menjamin tercapainya fungsi hukum sebagai rekayasa masyarakat kearah yang lebih baik, maka bukan hanya dibutuhkan ketersediaan hukum dalam arti kaidah atau peraturan, melainkan juga adanya jaminan atas perwujudan kaidah hukum tersebut ke dalam praktek hukum, atau dengan kata lain, jaminan akan adanya penegakan hukum (law enforcement) yang baik ${ }^{18}$. Jadi bekerjanya hukum bukan hanya merupakan fungsi perundangundangannya belaka, malainkan aktifitas birokrasi pelaksananya ${ }^{19}$,

Dalam perkembangannya saat ini maka dirasakan para penegak hukum dalam mengambil keputusan hanya berdasarkan aturan atau legal formal atau berparadigma positivisme. Karena memang sebagian besar kurikulum yang disampaikan kepada mahasiswa hukum mengacu paradigma positivisme, semuanya harus berdasarkan aturan yang ada dan tertulis.

Karena sejak awal dididik dengan metode demikian maka pada saat nanti para penegak hukum terjun di lapangan pekerjaan juga masih membawa paradigma yang dia pelajari selama ini bahwa hukum itu adalah peraturan yang tertulis, sehingga dalam pemecahan kasus dia juga berpedoman pada pasalpasal yang ada.

18 Munir Fuady, 2003, Perseroan Terbatas Paradigma Baru, Citra Aditya Bakti, Bandung, hlm.40.

19 Achmad Ali, 2002, Menguak Tabir Hukum Suatu Kajian Filosofis dan Sosiologis, PT. Gunung Agung Tbk, Jakarta, hlm. 97 c. Budaya hukum

Mengenai budaya hukum Friedman menjelaskan ${ }^{20}$

"The third component of legal system, of legal culture. By this we mean people's attitudes toward law and legal system their belief ...in other word, is the climinate of social thought and social force wicch determines how law is used, avoided, or abused". Artinya: Komponen ketiga dari sistem hukum, budaya hukum. Dengan ini dimaksudkan sikap masyarakat terhadap hukum dan sistem hukum kepercayaan mereka, dengan kata lain, adalah climinate pemikiran sosial dan kekuatan sosial menentukan bagaimana hukum digunakan, dihindari, atau disalahgunakan.

Kultur hukum menyangkut budaya hukum yang merupakan sikap manusia terhadap hukum dan sistem hukum. Sebaik apapun penataan struktur hukum untuk menjalankan aturan hukum yang ditetapkan dan sebaik apapun kualitas substansi hukum yang dibuat tanpa didukung budaya hukum oleh orangorang yang terlibat dalam sistem dan masyarakat maka penegakan hukum tidak akan berjalan secara efektif.

Problematika yang terjadi pada aspek budaya hukum menyangkut penyelesaian permasalahan kesejahteraan awak kapal di kapal Indonesia adalah:

1) Kurangnya kesadaran dan pemahaman Pelaut Indonesia tentang Undang - Undang Nomor 17 Tahun 2008 tentang Pelayaran ${ }^{21}$.

Salah satu faktor penting dalam implementasi Undang-Undang Nomor 17 Tahun 2008 tentang Pelayaran adalah peran serta masyarakat utamanya pelaut dalam penegakan aturan sesuai Undang-Undang yang berlaku. Untuk mewujudkan

20 Lawrence M. Friedman, Loc. Cit.,

21 Undang-Undang Nomor 17 Tahun 2008 tentang Pelayaran 
hal tersebut tentusaja para pelaut harus sadar dan yakin bahwa fungsi Undang-Undang pelayaran salah satunya adalah memberikan perlindungan hukum bagi para pelaut tersebut.

Maka penulis menambahkan bahwa faktor pertama agar seseorang sadar dan yakin tentang sebuah norma hukum adalah dia paham tentang aturan norma tersebut. Masih rendahnya pemahaman pelaut tentang Undang-Undang Nomor 17 Tahun 2008 menjadi salah satu kendala implementasinya. Perlu dilaksanakan sosialisasi tentang Undang-undang pelayaran secara periodik sehingga pelaut lebih memahami tentang isi dan manfaat peraturan tersebut. Faktor kedua adalah kurangnya kepedulian dari pelaut yang sudah mempunyai pemahaman tentang undang undang pelayaran. Bila pelaut tersebut sadar dan yakin kepada peraturan yang ada maka dibuktikan dengan perilaku yang mencerminkan ketaatan dan kepatuhan terhadap hukum tersebut. Rendahnya kesadaran untuk melaporkan setiap pelanggaran terhadap peraturan adalah cermin dari ketidakpatuhan terhadap hukum.

2) Kurangnya kompetensi pendidikan formal pelaut

Pelaut Indonesia banyak dihadapkan pada berbagai tantangan dan permasalahan. Kemampuan yang dimiliki tenaga pelaut Indonesia untuk menembus pasar global terancam bakal tersingkir. Hal ini disebabkan karena etos kerja pelaut Indonesia di luar negeri dinilai telah menurun. Tetapi penilaian tersebut, kini telah berubah karena berbagai tindakan tidak disiplin, di antaranya sering berbuat onar dan tidak ada penegakan hukum dari pemerintah maupun oleh asosiasi pelaut di Indonesia ${ }^{22}$.

Selain itu juga terjadi kesenjangan

22 Badan Penelitian dan Pengembangan Departemen Perhubungan RI, 2005. Op.Cit. hlm. 76. sosial antara pelaut Indonesia yang diperkerjakan pada kapal asing dan pada kapal Indonesia, adanya perbedaan diantaranya adalah tentang kesejahteraan, selain mengalami penurunan pada tenaga pelaut yang dikapal asing, juga terjadi penurunan kinerja pada kapal Indonesia, hal tersebut dikarenakan kesejahteraan tersebut tidak berimbang antara kerja dan reward, maka dari itu perlu adanya harmonisasi perlindungan hukum pada pelaut indonesia.

3) Rendahnya kedisiplinan pelaut untuk mengelola pendapatan hasil bekerja di laut.

Pengelolaan keuangan menjadi salah satu kunci dalam mewujudkan kesejahteraan keluarga. Besarnya pendapatan tidak akan ada artinya tanpa pengelolaan keuangan yang baik. Hal ini pula yang terjadi dengan sebagian besar pelaut di Indonesia, rendahnya kedisiplinan dalam pengelolaan pendapatan sangatlah penting untuk menjamin kehidupan di hari tua.

\section{Rekonstruksi perlindungan hukum pelaut di Kapal Indonesia berbasis nilai keadilan}

Terwujudnya kesejahteraan yang setara dengan pelaut yag bekerja di kapal asing, sementara saat ini kesejahteraan yang diberikan. Sesuai Pasal 151 Undang-Undang Nomor 17 Tahun 2008 tentang Pelayaran, disebutkan bahwa ${ }^{23}$ : kesejahteraan pelaut meliputi gaji, jam istirahat, jaminan pemberangkatan ke tempat tujuan dan pemulangan ke tempat asal, kompensasi apabila kapal tidak dapat beroperasi karena mengalami kecelakaan, kesempatan mengembangkan karier, pemberian akomodasi, fasilitas rekreasi, makanan atau minuman, pemeliharaan dan perawatan kesehatan serta pemberian asuransi kecelakaan kerja.

Segala sesuatu yang berhubungan dengan kesejahteraan awak kapal tercantum

23 Undang-Undang Nomor 17 Tahun 2008 Tentang Pelayaran 
di dalam Perjanjian Kerja Laut yang mana hanya menyangkut dua belah pihak yaitu awak kapal yang bersangkutan dan Perusahaan tempat bekerja.

Hal tersebut tentu saja menjadi sesuatu yang tidak menguntungkan bagi pekerja dalam hal ini awak kapal, karena ada kemungkinan awak kapal tidak tahu atau masih awam terhadap hukum tetapi harus menerima konsekuensi yang tertulis di dalam PKL yang mungkin tidak dipahami.

Sesuai dengan Peraturan Pemerintah Nomor 7 Tahun 2000 dijelaskan mengenai kesejahteraan pelaut, meliputi ${ }^{24}$ :

1) Jam Kerja yang meliputi (Pertama. Jam kerja bagi awak kapal ditetapkan 8 (delapan) jam setiap hari dengan 1 (satu) hari libur setiap minggu dan hari-hari libur resmi; Kedua Perhitungan gaji jam kerja bagi awak kapal ditetapkan 44 (empat puluh empat) jam setiap minggu. Ketiga Jam kerja melebihi ketentuan sebagaimana dimaksud dalam ayat (2) dan dipekerjakan pada hari-hari libur sebagaimana dimaksud dalam ayat (1) dihitung lembur; keempat Setiap awak kapal harus diberikan waktu istirahat palin sedikit 10 (sepuluh) jam dalam jangka waktu 24 (dua puluh empat) jam yang dapat dibagi 2 (dua), yang salah satu diantaranya tidak kurang dari 6 (enam) jam kecuali dalam keadaan darurat. Kelima Pelaksanaan tugas tugas darurat demi keselamatan berlayar dan muatan termasuk latihan-latihan di kapal atau untuk memberikan pertolongan dalam bahaya sesuai peraturan keselamatan pelayaran tidak dihitung lembur; keenam Pelaut muda atau pelaut yang berumur antara 16 tahun sampai 18 tahun dan dipekerjakan sebagai apapun di atas kapal; ketuju kapal tidak diperbolehkan untuk: a. Dipekerjakan melebihi 8 (delapan) jam kerja sehari dan 40 jam seminggu; $b$. Dipekerjakan pada waktu istirahat,

24 Peraturan Pemerintah Nomor 7 Tahun 2007 kecuali dalam hal-hal sebagaimana dimaksud dalam ayat (5). ${ }^{25}$

2) Gaji atau upah, meliputi tentang: 1) Upah minimum bagi awak kapal dengan jabatan terendah ditetapkan oleh Menteri yang bertanggung jawab di bidang ketenagakerjaan, berdasarkan ketentuan upah minimum tenaga kerja sesuai peraturan perundang - undangan yang berlaku.

2) Upah lembur per jam dihitung dengan rumus: Upah Minimum x 1,25,

3) Hari libur yang dibayar dihitung untuk setiap bulan 4 (empat) hari kerja, yang besarnya setiap hari $1 / 30$ (sepertigapuluh) dari gaji minimum bulanan. ${ }^{26}$

3) Cuti, meliputi tentang, 1) Setiap awak kapal berhak mendapatkan cuti tahunan yang lamanya paling sedikit 20 (dua puluh) hari kalender untuk setiap jangka waktu 1 (satu) tahun bekerja; 2) Atas permintaan pengusaha angkutan di perairan, awak kapal yang mendapatkan hak cuti tahunan dapat mengganti hak cutinya dengan imbalan upah sejumlah hari cuti yang tidak dinikmatinya.

4) Makanan, minuman dan perlengkapannya, 1) Pengusaha angkutan di perairan wajib menyediakan makanan dan alatalat pelayanan dalam jumlah yang cukup dan layak untuk setiap pelayaran bagi setiap awak kapal di atas kapal. 2) Makanan harus memenuhi jumlah, ragam serta nilai gizi dengan jumlah minimum 3600 kalori perhari yang diperlukan awak kapal untuk tetap sehat dalam melakukan tugas-tugasnya di kapal. 3) Air tawar harus tetap tersedia di kapal dengan jumlah yang cukup dam memenuhi standar kesehatan. 4)

25 International Maritime Organization, "Standards Of Training, Certification and Watchkeeping for Sailors Convention, As Amended in 1995".

26 "Undang - Undang Nomor 13 Tahun 2003 Tentang Ketenagakerjaan", Lembaran Negara Republik Indonesia Tahun 2003 Nomor 9. 
Alat-alat pelayanan seperti peralatan dapur dan atau peralatan memasak, serta perlengkapan ruang makan harus tersedia dalam jumlah yang cukup dan baik.

5) Pemulangan kembali ke daerah asal/ repatriasi, meliputi tentang: 1) Awak kapal yang habis masa kontrak kerjanya harus dikembalikan ke tempat domisilinya atau ke pelabuhan ditempat perjanjian kerja laut ditandatangani. 2) Jika awak kapal memutuskan hubungan kerja atas kehendak sendiri, pengusaha angkutan dibebaskan dari kewajiban pembiayaan untuk pemulangan yang bersangkutan. 3) Apabila masa kontrak dari awak kapal habis masa berlakunya pada saat kapal dalam pelayaran, awak kapal yang bersangkutan diwajibkan meneruskan pelayaran sampai di pelabuhan pertama yang disinggahi dengan mendapat imbalan upah dan kesejahteraan sejumlah hari kelebihan dari masa kontrak. Biayabiaya sebagaimana dimaksud ayat (1) dan ayat (3), merupakan tanggungan pengusaha angkutan di perairan yang meliputi biaya-biaya pemulangan, penginapan dan makanan sejak diturunkan dari kapal sampai tiba ditempat domisilinya.

Terdapat hal hal yang menjadikan benturan antara Benturan UndangUndang Pelayaran dan Ketenagakerjaan, maka sebaiknya Pemerintah segera menerbitkan Peraturan Pemerintah (PP) sebagai petunjuk pelaksanaan dan petunjuk teknis pelaksanaan UndangUndang Nomor 17 Tahun 2007 tentang Pelayaran, khususnya menyangkut kepelautan.

PP ini perlu segera diterbitkan untuk mencegah terjadinya tumpang tindih dan benturan dengan UndangUndang Nomor 13 Tahun 2003 tentang Ketenagakerjaan serta Undang-Undang 39 Tahun 2004 tentang Penempatan dan Perlindungan TKI di Luar Negeri. Desakan ini dikemukan Presiden KPI (Kesatuan Pelaut Indonesia), Masalah keagenan awak kapal (ship manning agent) atau berakitan dengan kepelautan diatur dalam pasal 31 UU 17 Tahun 2008. Masalah ini perlu diperjelas melalui PP agar tidak terjadi tumpang tindih, atau tabrakan dengan UU ketenagakerjaan, serta UU penempatan dan perlindungan TKI di luar negeri.

Hal yang dapat dilakukan guna menghindari tarik menarik kepentingan antar-departemen, KPI minta pemerintah segera mensosialisasikan pasal yang mengatur masalah keagenan awak kapal dengan melibatkan semua instansi terkait dan seluruh stakeholder. Rumusan PP nanti harus dapat menyatukan keselarasan keselamatan pelayaran dengan penempatan dan perlindungan pelaut yang dihargai dan diakui semua pihak, sehingga tidak ada friksi yang merugikan pelaut, tegasnya.

Undang-undang Nomor 39 Tahun 2004 tentang Penempatan dan Perlindungan TKI di Luar Negeri sama sekali tidak menyinggung tentang penempatan dan perlindungan pelaut. Namun, pasal 28 Undang-Undang Nomor 39/2004 menyebutkan penempatan TKI pada pekerjaan dan jabatan tertentu diatur lebih lanjut dengan keputusan menteri. Tapi peraturan menteri sebagai payung hukum penempatan dan perlindungan pelaut itu sampai sekarang belum terbit ${ }^{27}$.

Penjabaran pasal 28 UU 39/2004 itu akan membuka peluang interpretasi lain, sehingga bisa tumpang tindih atau berbenturan dengan pasal 31 Undang-Undang Pelayaran. Diharapkan Departemen Perhubungan dengan Depnakertrans membahas masalah kepelautan dengan cermat, sehingga rancangan peraturan yang akan dikeluarkan tidak bertabrakan dengan kedua undang-undang tersebut. PP baru

27 Undang-undang Nomor 39 Tahun 2004 tentang Penempatan dan Perlindungan TKI 
itu nantinya sekaligus menggantikan PP Nomor 7 Tahun 2000 tentang Kepelautan yang merupakan Juklak Undang-Undang Pelayaran Nomor 12 Tahun 1992 yang telah direvisi menjadi Undang-Undang Nomor Tahun 2008. Namun ketentuan mengenai kepelautan harus tetap mengacu pada KUHD (Kitab Undangundang Hukum Dagang, buku ke-2) dan aturan internasional yang tertuang dalam Maritime Labour Covention tahun $2006^{28}$.

Berdasarkan uraian di atas, Rekonstruksi Perlindungan Hukum Pelaut Di Kapal Indonesia Berdasarkan Nilai Keadilan adalah perlindungan hukum yang seimbang antara pelaut dan pengusaha Kapal Indonesia, guna mewujudkan kesejahteraan pelaut, harmonisasi kesejahteraan pelaut dan produktifitas Perusahaan Pelayaran Indonesia yang berbasis nilai keadilan.

\section{Penutup}

1. Kesimpulan

Berdasarkan kajian di atas, disimpulkan beberapa hal berikut:

a. Problematika perlindungan hukum pelaut di Kapal Indonesia saat ini adalah adanya :

1) Kelemahan Substansi Hukum

a) Pengaturan kesejahteraan mengenai gaji dan tunjangan masih bersifat umum belum ada standar yang baku tentang besaran gaji / upah minimum serta tunjangan kerja pelaut.

b) Belum diratifikasinya Maritime Labour Convention (MLC) oleh pemerintah Indonesia.

2) Kelemahan Struktur Hukum

a) Penyelesaian perselisihan hubungan industrial pelaut di Pengadilan Hubungan Industrial belum mampu menyelesaikan permasalahan yang terjadi. Di dalam Perjanjian Kerja Laut telah

$28 \quad$ Kitab Undang-Undang Hukum Dagang diatur mengenai tempat bekerja yaitu di atas kapal dengan lokasi yang selalu berpindah-pindah. Bila selama bertugas di atas kapal dengan tempat yang selalu berpindah-pindah maka kepastian tempat perselisihan juga menjadi masalah tersendiri.

b) Aparat penegak hukum yang masih berparadigma positivisme dalam mengambil keputusan di lembaga peradilan. Karena sejak awal dididik dengan metode demikian maka pada saat nanti para penegak hukum terjun di lapangan pekerjaan juga masih membawa paradigma yang dia pelajari selama ini bahwa hukum itu adalah peraturan yang tertulis, sehingga dalam pemecahan kasus dia juga berpedoman pada pasal-pasal yang ada.

3) Kelemahan Budaya Hukum.

a) Kurangnya kesadaran dan pemahaman Pelaut Indonesia tentang Undang-Undang Nomor 17 Tahun 2008 Tentang Pelayaran. Salah satu faktor penting dalam implementasi Undang-Undang Nomor 17 Tahun 2008 tentang Pelayaran untuk mewujudkan hal tersebut tentusaja para pelaut harus sadar dan yakin bahwa fungsi undangundang pelayaran salah satunya adalah memberikan perlindungan hukum bagi para pelaut tersebut. Kurangnya kesadaran dan pemahaman pelaut tentang undangundang atau peraturan yang terkait menjadi faktor penghambat implementasi di lapangan. 
b) Kurangnya kompetensi pendidikan formal pelaut. Kemampuan yang dimiliki tenaga pelaut Indonesia untuk menembus pasar global terancam bakal tersingkir. Hal ini disebabkan karena etos kerja pelaut Indonesia di luar negeri dinilai telah menurun.

c) Rendahnya kedisiplinan pelaut untuk mengelola pendapatan hasil bekerja di laut. Besarnya pendapatan tidak akan ada artinya tanpa pengelolaan keuangan yang baik. Rendahnya kedisiplinan dalam pengelolaan pendapatan sangatlah penting untuk menjamin kehidupan di hari tua.

b. Pembaharuan perlindungan hukum pelaut di Kapal Indonesia, meliputi:

1) Pembaharuan nilai perlindungan hukum pelaut di Kapal Indonesia berdasarkan nilai keadilan yaitu perlindungan hukum yang seimbang antara pelaut dan pengusaha Kapal Indonesia.

2) Pembaharuan hukumnya, yaitu:

\section{No Sebelum Pembaharuan}

Pasal 151 (1) UU No.17 Tahun

2008 Tentang Pelayaran

berbunyi : Setiap awak

kapal berhak mendapatkan

kesejahteraan yang meliputi

: gaji, jam istirahat, jaminan pemberangkatan ke tempat tujuan dan pemulangan ke tempat asal, kompensasi apabila kapal tidak dapat beroperasi karena mengalami kecelakaan, kesempatan mengembangkan karier, pemberian akomodasi, fasilitas rekreasi, makanan atau minuman, pemeliharaan dan perawatan kesehatan serta pemberian asuransi kecelakaan kerja

Pasal 169 (1) UU No.17 Tahun 2008 Tentang Pelayaran berbunyi : Pemilik atau operator kapal yang mengoperasikan

2 kapal untuk jenis dan ukuran tertentu harus memenuhi persyaratan manajemen keselamatan dan pencegahan pencemaran dari kapal.

Pasal 21 (2) PP No.7 Tahun 2000 berbunyi : Perhitungan

3 gaji jam kerja bagi awak kapal ditetapkan 44 (empat puluh empat) jam setiap minggu

\section{Kelemahan - kelemahan}

Tidak merinci regulasi kesejahteraan pelaut di Kapal Indonesia

Sanksi yang diberikan bila pemilik kapal dan operator kapal melanggar aturan ini adalah sanksi administratif

Terjadi kesenjangan gaji pelaut di Kapal Indonesia dan Pelaut di Kapal Asing

\section{Pembaharuan Hukum}

Pasal 151 (1) UU No.17 Tahun 2008 Tentang Pelayaran berbunyi: Setiap awak kapal berhak mendapatkan kesejahteraan yang meliputi: gaji, jam istirahat, jaminan pemberangkatan ke tempat tujuan dan pemulangan ke tempat asal, kompensasi apabila kapal tidak dapat beroperasi karena mengalami kecelakaan, kesempatan mengembangkan karier, pemberian akomodasi, fasilitas rekreasi, makanan atau minuman, pemeliharaan \& perawatan kesehatan serta pemberian asuransi kecelakaan kerja, dan mendapatkan kesejahteraan yang sesuai dengan standar yang telah ditetapkan di dalam Maritime Labour Convention 2006.

Pasal 169 (1) UU No.17 Tahun 2008 Tentang Pelayaran berbunyi : Pemilik atau operator kapal yang mengoperasikan kapal untuk jenis dan ukuran tertentu harus memenuhi persyaratan manajemen keselamatan dan pencegahan pencemaran dari kapal, pelanggaran atas ketentuan ini akan dikenakan sanksi pidana dan sanksi administratif.

Pasal 21 (2) PP No.7 Tahun 2000 berbunyi : Perhitungan gaji jam kerja bagi awak kapal ditetapkan 44 (empat puluh empat) jam setiap minggu dan sesuai dengan standar gaji yang ditetapkan Maritime Labour Convention 2006. 
2. Saran

Pengkajian ini masih memiliki kekurangan yaitu keterbatasan pada problem-problem yang dialami pelaut, oleh karena itu untuk kemajuan penelitian kedepannya masih perlu pengkajian dari permasalahan-permasalahan yang ada di atas, menyarankan hal-hal yang bisa dilakukan oleh Pemerintah yaitu:

1) Pemerintah perlu mengamandemen Peraturan Pemerintah Nomor 7 Tahun 2000 Tentang Kepelautan khususnya Pasal 21 (2) yang berbunyi: Perhitungan gaji jam kerja bagi awak kapal ditetapkan 44 (empat puluh empat) jam setiap minggu, dan Pasal 22 (1) yang berbunyi: Upah minimum bagi awak kapal dengan jabatan terendah ditetapkan oleh Menteri yang bertanggung jawab di bidang ketenagakerjaan, berdasarkan ketentuan upah minimum tenaga kerja sesuai peraturan perundangundangan yang berlaku.

2) Pemerintah memastikan perlindungan hukum termasuk gaji, dan kesejahteraan pelaut Indonesia di kapal dalam negeri, dengan melaksanakan pengawasan dan pembinaan kepada perusahaan pelayaran dalam negeri.

3) Pemerintah melaksanakan sosialisasisosialisasi untuk meningkatkan pemahaman dan kesadaran hukum kepada seluruh pelaut baik yang bekerja di Kapal Indonesia maupun di kapal asing sehingga pelaut paham akan hak, kewajiban dan seluruh regulasi yang berlaku berkenaan dengan pelaksanaan tugasnya di atas kapal.

\section{DAFTAR PUSTAKA}

Achmad Ali. 2002. Menguak Tabir Hukum Suatu Kajian Filosofis dan Sosiologis, PT. Gunung Agung Tbk. Jakarta.

Boby R. Mamahit. 2011. Krisis SDM Masih Belum Bisa Teratasi, Suara Karya, 26 Januari.

Dedi Darmawan, "Perusahaan Pelayaran Nasional Diimbau Aktif Mengembangkan Tenaga Pelaut", Berita Pusat Komunikasi Publik Kementerian Perhubungan, 13 April, 2010

Direktorat Jenderal Perhubungan Laut dan INSA (Asosiasi Pengusaha Pelayaran Seluruh Indonesia) Tahun 2005.

Esmi Warassih. 2005. Pranata Hukum Sebuah Telaah Sosiologis. Semarang: Suryandaru Utama, dikutip dari Thomas R. Dye, “Understanding Public Policy”, Prentice Hall, Inc. 1978

http://en.wikipedia.org/wiki//ndonesia.

Instruksi Presiden Nomor 5 Tahun 2005.

International Maritime Organization, "Standards Of Training, Certification and Watchkeeping for Sailors Convention, As Amended in 1995".

Kitab Undang-Undang Hukum Dagang.

Lawrence M. Friedman. 1984. American Law: An invalueable guide to the many faces of the law, and how it affects our daily lives, New York: W.W. Norton \& Company.

Maritime Labour Convention", 7 February, 2006.

Munir Fuady. 2003. Perseroan Terbatas Paradigma Baru, Citra Aditya Bakti, Bandung.

Peraturan Pemerintah Nomor 7 Tahun 2007 tentang Pelaksaan Undang-Undang Nomor 7 Tahun 2008 tentang Pleyaran. 
Tri Cahyadi. Rekonstruksi Perlindungan Hukum Pelaut Di Kapal Indonesia Berbasis Nilai Keadilan Disertasi PDIH Unissula. Semarang.

Tubrukan Antara KM. Indimatam V dengan KM. Trisal Pratama, Investigasi Kecelakaan Kapal Laut KNKT. Januari. 2011.

Undang - Undang Nomor 13 Tahun 2003 Tentang Ketenagakerjaan, Lembaran Negara Republik Indonesia Tahun 2003 Nomor 9.

Undang - Undang Nomor 17 Tahun 2008 Tentang Pelayaran, Lembaran Negara Republik Indonesia Tahun 2008 Nomor 64.

Undang-undang Nomor 39 Tahun 2004 tentang Penempatan dan Perlindungan TKI 